\title{
Власний досвід застосування відеоасистованої паратиреоїдектомії для лікування паціентів із первинним гіперпаратиреозом
}

\begin{abstract}
Мета роботи: вивчити переваги та недоліки відеоасистованої паратиреоїдектомії.
Матеріали і методи. У нашій клініці від лютого 2010 року до лютого 2019 року оперовано 103 пацієнти з приводу ПГпТ, з них було 84 жінки, середній вік хворих склав $(58,2 \pm 12,1)$ року. Діагноз ПГПТ базувався на класичних симптомах, а саме наявності підвищених рівнів загального та/або йонізованого кальцію та інтактного паратгормону (ПТГ) у сироватці крові. Усіх пацієнтів розділено на дві групи: I група - 36 пацієнтів (35 \%), яким виконано відеоасистовану паратиреоїдектомію, II група 67 пацієнтів (65 \%), яких оперували відкритим способом із двобічною експлорацією шиї.

Результати досліджень таїх обговорення. У 35 \% хворих виконано відеоасистовану паратиреоїдектомію, у яких за результатами топічних досліджень виявлено солітарну аденому ПЩ3 - ці пацієнти утворили I групу. У 59 (57 \%) хворих II групи виявлено супутню патологію щитоподібної залози, 4 пацієнти (4 \%) в анамнезі мали операції на шиї в ділянці щитоподібної залози, ще у 4-х (4 \%) - діагностовано рецидив або персистенцію ПГПТ. Обидві групи вірогідно не відрізнялися за віком та статтю, рівнями загального та йонізованого кальцію, ПТГ перед операційним втручанням. Тривалість операційного втручання була вірогідно меншою та довжина розтину коротшою у пацієнтів I групи. У двох (2 \%) хворих II групи та у жодного пацієнта I групи після операційного втручання розвинувся транзиторний парез поворотного гортанного нерва. Отримані результати дозволяють твердити, що відеоасистована паратиреоїдектомія у ретельно відібраних пацієнтів (35 \%), за результатами ультрасонографії та сумнівних випадках сцинтиграфії із 99mTс-MIBI, є ефективним мініінвазійним методом операційного лікування хворих на ПГПт, який дозволяє скоротити час хірургічного втручання та частоту післяопераційних ускладнень.
\end{abstract}

Ключові слова: відеоасистована паратиреоїдектомія; лікування; первинний гіперпаратиреоз.

Постановка проблеми і аналіз останніх досліджень та публікацій. Первинний гіперпаратиреоз (ПГПТ) у розвинених країнах діагностують у $1 \%$ населення, причому частота хвороби зростає 3 віком від 10 / 100000 населення до 40 років аж до 60 / 100000 населення після 60 років. Як відомо, аденома лише однієї прищитоподібної залози (ПЩЗ) спричиняє ПГПТ у 80-90 \% пацієнтів, що дозволяє хворити про можливість виконання сфокусованої паратиреоїдектомії в більшості хворих [1].

Точна локалізація патологічної ПЩЗ є головною передумовою успішного виконання мініінвазивного втручання у пацієнтів із ПГПТ. Ультрасонографія (УСГ) шиї та сцинтиграфія із використанням Tc99m-sestamibi $€$ головними методами локалізації у цих хворих. Ультрасонографія є дешевим, неінвазивним методом дослідження, під час якого пацієнт не піддається впливу радіаційного опромінення, тому застосовується у всіх хворих. Слід взяти до уваги, що, відповідно до літературиних повідомлень, чутливість УСГ у локалізації патологічних ПЩЗ залежить від радіолога, який iї виконує та складає від 33 до 92 \%.

Для запровадження у нашій клініці малоінвазивних втручань на ПЩЗ ми обрали відеоасистовану паратиреоїдектомію, запропоновану P. Miccoli у 1998 році [8]. Адже ця операція поєднує переваги ендоскопічних та відкритих втручань, а саме: ма- лу травматичність, використання ендоскопа та інструментів для відкритих операцій на щитоподібній залозі та ПЩЗ, можливість при потребі з одного доступу провести експлорацію шиї з обох сторін, тобто провести втручання навіть у пацієнтів без прецизійної передопераційної топічної діагностики, виконати симультанне мініінвазивне втручання на щитоподібній залозі, що є неможливим під час повністю ендоскопічних втручань, швидкий перехід до конвенційного втручання, адже для цього потрібно лише збільшити розтин шкіри [2].

Матеріали і методи. У нашій клініці від лютого 2010 року до лютого 2019 року оперовано 103 пацієнти з приводу ПГПТ, з них було 84 жінки, середній вік хворих склав $(58,2 \pm 12,1)$ року.

Діагноз ПГПТ базувався на класичних симптомах, а саме наявності підвищених рівнів загального та/або йонізованого кальцію та інтактного ПТГ у сироватці крові. Крім цього, визначали рівні неорганічного фосфору, хлору, лужної фосфатази, ү-глутамілтранспептидази у сироватці крові, кальцій у добовій сечі.

Для передопераційної топічної діагностики застосовували ультрасонографію, яку виконували два радіологи і за потреби сцинтиграфію із 99mTc-MIBI та 99mTc-пертехнетатом (променеве навантаження 2,7 м3в (320 мБк)). 
Усіх пацієнтів розділено на дві групи: I група - 36 пацієнтів (35 \%), яким виконано відеоасистовану паратиреоїдектомію, II група - 67 пацієнтів (65 \%), яких оперували відкритим способом із двобічною експлорацією шиї. Критеріями включення пацієнтів до I групи стали: спорадичний ПГПТ, відсутність операцій на шиї у анамнезі, відсутність патології щитоподібної залози, яка потребує хірургічного лікування, переконливі ознаки наявності солітарної аденоми ПщЗ за результатами ультрасонографії i/або сцинтиграфії із 99mTc-MIBI.

Операційне втручання проводили під загальним знеболенням. Положення пацієнта таке ж, як під час хірургічного втручання на щитоподібній залозі, але без перерозгинання у шийному відділі хребта, щоб не зменшувати операційний простір під короткими м'язами шиї. Проводили розтин шкіри та підшкірної клітковини за Кохером завдовжки від 20 до 25 мм, у безкровний спосіб розсували по білій лінії короткі м'язи шиї та оголювали передню поверхню щитоподібної залози. Ретрактором відводили щитоподібну залозу медіально та візуалізували загальну сонну артерію. За допомогою марлевих серветок створювали порожнину між бічною та задньою поверхнями відповідної частки щитоподібної залози та загальною сонною артерією. Для візуалізації ПЩЗ та поворотного гортанного нерва використовували скошений під кутом $30^{\circ} 5$ мм ендоскоп. У створеній порожнині за допомогою 2 мм шпателів тупим шляхом виділяли аденому між задньою поверхнею щитоподібної залози та стравоходом зліва або трахеєю справа, кліпували або перев'язували судинну ніжку аденоми та видаляли їі. Спираючись на літературні дані було вирішено, що якщо пошуки патологічної ПЩЗ будуть тривати більше 120 хв, то слід перейти до відкритої двобічної експлорації шиї.

Результати досліджень та їх обговорення. За час проведення дослідження, у 35 \% хворих виконано відеоасистовану паратиреоїдектомію, у яких за результатами топічних досліджень виявлено солітарну аденому ПЩЗ та не виявлено патології щитоподібної залози - ці пацієнти утворили I групу. У 59 (57 \%) хворих II групи виявлено супровідну патологію щитоподібної залози, 4 пацієнти (4 \%) в анамнезі мали операції на шиї в ділянці щитоподібної залози, ще у 4-х (4 \%) - діагностовано рецидив або персистенцію ПГПТ. У однієї пацієнтки із рецидивом ПГПТ за результатами ультрасонографії на шиї не вдалося виявити гіперфункціонуючої тканини ПЩЗ, а за допомогою сцинтиграфії із 99mTc-MIВI виявлено аденому ПЩЗ розташовану у передньому верхньому середостінні, для її видалення виконано торакотомію.

Дві групи пацієнтів порівняли за основними показниками, які наведено у таблиці 1. Обидві групи вірогідно не відрізнялися за віком та статтю, рівнями загального та йонізованого кальцію, ПТГ перед операційним втручанням. Тривалість

Таблиця 1. Характеристика показників у групах

\begin{tabular}{|c|c|c|c|}
\hline Основні показники & $\begin{array}{c}\text { I група } \\
\text { n = } 36\end{array}$ & $\begin{array}{c}\text { II група } \\
\text { n = } 67\end{array}$ & $\mathrm{p}$ \\
\hline Середній вік хворих (роки) & $53,7 \pm 9,2$ & $59,3 \pm 10,8$ & $>0,05$ \\
\hline Співвідношення жінки:чоловіки & $6: 1$ & $5: 1$ & \\
\hline Загальний кальцій перед операцією (ммоль/л) & $2,84 \pm 0,21$ & $2,92 \pm 0,19$ & $>0,05$ \\
\hline Йонізований кальцій перед операцією (ммоль/л) & $1,49 \pm 0,11$ & $1,47 \pm 0,09$ & $>0,05$ \\
\hline ПТГ перед операцією (pg/ml) & $137,1 \pm 27,8$ & $144,2 \pm 19,5$ & $>0,05$ \\
\hline Тривалість операції (хв) & $46 \pm 15,4$ & $101 \pm 16,1$ & $<0,05$ \\
\hline Довжина розтину (см) & $2,7 \pm 0,3$ & $6,1 \pm 1,1$ & $<0,05$ \\
\hline Тривалість госпіталізації (діб) & $3 \pm 1$ & $5 \pm 1,2$ & $>0,05$ \\
\hline Йонізований кальцій після операції (ммоль/л) & $1,17 \pm 0,06$ & $1,08 \pm 0,11$ & $>0,05$ \\
\hline Кількість пацієнтів із транзиторним гіпопаратиреозом (n) & 3 & 14 & \\
\hline $\begin{array}{l}\text { Кількість пацієнтів із транзиторним парезом поворотного } \\
\text { гортанного нерва (n) }\end{array}$ & 0 & 2 & \\
\hline
\end{tabular}




\section{З ДОСВІДУ РОБОТИ}

операційного втручання була вірогідно меншою та довжина розтину коротшою у пацієнтів I групи. Причому у перших 4 пацієнтів, яким виконали відеоасистовану паратиреоїдектомію, хірургічне втручання тривало більше 60 хвилин, а у останніх 4 хворих - менше 45 хв. Ми статистично не порівнювали частоту транзиторного гіпопаратиреозу у хворих обох груп, тому що у пацієнтів II групи, у яких розвинулося це ускладнення, ми спостерігали множинне ураження ПЩЗ. У двох (2 \%) хворих II групи та у жодного пацієнта I групи після операційного втручання розвинувся транзиторний парез поворотного гортанного нерва. Не у всіх пацієнтів нам вдалося візуалізувати поворотний гортанний нерв під час відеоасистованої паратиреоїдектомії.

Усім пацієнтам виконували ультрасонографію два радіологи. У 24 (23 \%) пацієнтів I групи ультрасонографічно виявили солітарний гіпоехогенний чітко окреслений утвір розташований дозаду від щитоподібної залози, який було беззаперечно розцінено як аденому ПЩЗ. Під час ультрасонографічного дослідження у 12 (12 \%) інших хворих цієї групи виникли сумніви стосовно локалізації патологічної ПЩЗ. Цим пацієнтам виконано сцинтиграфію із 99mTc-MIBI та підтверджено наявність солітарного утвору ПЩЗ.

\section{СПИСОК ЛІТЕРАТУРИ}

1. Primary hyperparathyroidism: incidence and clinical and biochemical characteristics. A Demographic study / C. L. Mollerup, J. Bollerslev, M. Blichert-Toft [et al.] // Eur. J. Surg. - 1994. - Vol. 160. - P. 485-489.

2. Minimally invasive parathyroidectomy without intraoperative PTH performed after positive ultrasonography as the only diagnostic method in patients with primary hyperparathyroidism / R. Schneider, J. Hinrichs, B. Meier [et al.] // World J. Surg. 2019. - Vol. 43 (6). - P. 1525-1531.

3. The natural history of primary of primary hyperparathyroidism
Під час операційного втручання в усіх хворих виявлено патологічні ПЩЗ. Ефективність відеоасистованої паратиреоїдектомії підтверджували експрес-гістологічним інтраопераційним дослідженням. У однієї хворої І групи було виконано конверсію, коли експрес-гістологія засвідчила, що видалений утвір - це лімфатичний вузол. Після конверсії вдалося виявити та видалити аденому ПЩЗ, яка була розташована більш каудально. У 19 (19 \%) пацієнтів II групи виявлено множинне ураження ПЩЗ та видалено більше однієї патологічної ПЩЗ: у 9 (9 \%) видалено дві гіперплазовані ПЩ3, у двох (2 \%) - три гіперплазовані ПЩЗ, ще у 8-ми (8 \%) хворих видалено дві аденоми ПЩЗ.

Після операції в усіх пацієнтів нормалізувався або знизився нижче норми рівень йонізованого кальцію.

Висновки. Отримані результати дозволяють твердити, що відеоасистована паратиреоїдектомія у ретельно відібраних пацієнтів (35 \%), за результатами ультрасонографії та у сумнівних випадках сцинтиграфії із 99mTc-MIBI, є ефективним мініінвазійним методом операційного лікування хворих на ПГПТ, який дозволяє скоротити час хірургічного втручання та частоту післяопераційних ускладнень.

with or without parathyroid surgery after 15 years / M. R. Rubin, J. P. Bilezikian, D. J. McMahon [et al.] // J. Clin. Endocrinol. Metab. - 2008. - Vol. 93. - P. 3462-3470.

4. Ultrasonography alone can reliably locate parathyroid tumours and facilitates minimally invasive parathyroidectomy / H. Z. Butt, M. A. Husainy, A. Bolia [et al.] // Ann. R. Coll. Surg. Engl. - 2015. - Vol. 97. - P. 420-424.

5. Endoscopic parathyroidectomy: report of an initial experience / P. Miccoli, C. Bendinelli, E. Vignali [et al.] // Surgery. - 1998. Vol. 124. - P. 1077-1080.

\section{REFERENCES}

1. Mollerup, C.L., Bollerslev, J., \& Blichert-Toft, M. (1994). Primary hyperparathyroidism: incidence and clinical and biochemical characteristics. A Demographic study. Eur. J. Surg., 160, 485-489.

2. Schneider, R., Hinrichs, J., Meier, B., Walz, M.K., \& Alesina, P.F. (2019). Minimally invasive parathyroidectomy without intraoperative PTH performed after positive ultrasonography as the only diagnostic method in patients with primary hyperparathyroidism. World J. Surg., 43 (6), 1525-1531. 3. Rubin, M.R., Bilezikian, J.P., \& McMahon, D.J. (2008). The natural history of primary of primary hyperparathyroidism with or without parathyroid surgery after 15 years. J. Clin. Endocrinol. Metab., 93, 3462-3470.

4. Butt, H.Z., Husainy, M.A., \& Bolia, A. (2015). Ultrasonography alone can reliably locate parathyroid tumours and facilitates minimally invasive parathyroidectomy. Ann. R. Coll. Surg. Engl., 97, 420-424.

5. Miccoli, P., Bendinelli, C., \& Vignali, E. (1998) Endoscopic parathyroidectomy: report of an initial experience. Surgery, 124, 1077-1080. 
Danylo Halytskyi Lviv National Medical University ${ }^{1}$

Lviv Regional Clinical Hospital ${ }^{2}$

\title{
OWN EXPERIENCE OF THE USE OF VIDEO-ASSISTED PARATHYROIDECTOMY FOR TREATMENT OF PATIENTS WITH PRIMARY HYPERPARATHYROIDISM
}

\begin{abstract}
The aim of the work: to study the advantages and disadvantages of video-assisted parathyroidectomy.
Materials and Methods. In our clinic, from February 2010 to February 2019, 103 patients were operated on for primary hyperparathyroidism (PHPT), among whom 84 were women, the average age of the patients was $(58.2 \pm 12.1)$ years. The diagnosis of PHPT was based on classic symptoms, namely the presence of elevated levels of total and/or ionized calcium and intact parathyroid hormone in the blood serum. All patients were divided into two groups: group I - 36 patients (35\%) who underwent video-assisted parathyroidectomy, and group II - 67 patients (65 \%) who were operated on conventionaly with bilateral neck exploration.

Results and Discussion. In $35 \%$ of patients, video-assisted parathyroidectomy was performed, in whom, according to the results of topical studies, a solitary thyroid adenoma was revealed - these patients formed group I. An accompanying thyroid pathology was revealed in 59 (57 \%) patients of group II, 4 patients (4\%) had a history of neck surgery in the area of thyroid gland, and $4(4 \%)$ were diagnosed with relapse or persistence of PHPT. Both groups did not significantly differ in age and gender, levels of total and ionized calcium, parathyroid hormone before surgery. The duration of surgery was significantly shorter and the length of the incision was shorter in patients of group I. In two (2 \%) patients of group II and no patient of group I after surgery developed a transient paresis of the recurrent laryngeal nerve. The results suggest that video-assisted parathyroidectomy in carefully selected patients (35\%), according to the results of ultrasound and in doubtful cases of scintigraphy with 99mTc-MIBI, is an effective minimally invasive operation for the treatment of patients with PHPT, which allows to reduce the time of surgical intervention and the frequency of postoperative complications.
\end{abstract}

Key words: videoassisted parathyroidectomy; treatment; primary hyperparathyroidism.

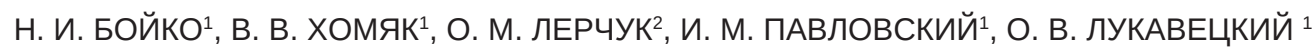

Львовский национальный медицинский университет имени Данила Галицкого ${ }^{1}$

Львовская областная клиническая больница ${ }^{2}$

\section{СОБСТВЕННЫЙ ОПЫТ ПРИМЕНЕНИЯ ВИДЕОАССИСТИРОВАННОЙ ПАРАТИРЕОИДЭКТОМИИ ДЛЯ ЛЕЧЕНИЯ ПАЦИЕНТОВ С ПЕРВИЧНЫМ ГИПЕРПАРАТИРЕОЗОМ}

\begin{abstract}
Цель работы: изучить преимущества и недостатки видеоассистированной паратиреоидэктомии.
Материалы и методы. В нашей клинике с февраля 2010 по февраль 2019 года оперированы 103 пациента по поводу первичного гиперпаратиреоза (ПГПТ), из них было 84 женщины, средний возраст больных составил $(58,2 \pm 12,1)$ года. Диагноз ПГПТ базировался на классических симптомах, а именно наличия повышенных уровней общего и/или ионизированного кальция и интактного паратгормона в сыворотке крови. Всех пациентов разделили на две группы: I группа - 36 пациентов (35 \%), которым выполнено видеоассистированную паратиреоидэктомию, и II группа - 67 пациентов (65 \%), которых оперировали открытым способом с двусторонней эксплорацией шеи.

Результаты исследований и их обсуждение. В 35 \% больных выполнено видеоассистированную паратиреоидэктомию, в которых по результатам топических исследований выявлено солитарную аденому ПЩЖ - эти пациенты образовали I группу. В 59 (57 \%) больных II группы выявлено сопроводительную патологию щитовидной железы, 4 пациента (4 \%) в анамнезе имели операции на шее в области щитовидной железы, еще в 4-х (4 \%) - диагностирован рецидив или персистенцию ПГПТ. Обе группы достоверно не отличались по возрасту и полу, уровнями общего и ионизированного кальция, паратгормона перед операционным вмешательством. Продолжительность операционного вмешательства была достоверно меньше и длина разреза короче у пациентов I группы. В двух (2 \%) больных II группы и у ни одного пациента I группы после операционного вмешательства развился преходящий парез возвратного гортанного нерва. Полученные результаты позволяют утверждать, что видеоассистированная паратиреоидэктомия в тщательно отобранных пациентов (35\%), по результатам ультрасонографии и в сомнительных случаях сцинтиграфии с 99mTc-MIBI, является эффективной миниинвазивной операцией для лечения больных ПГПТ, которая позволяет сократить время хирургического вмешательства и частоту послеоперационных осложнений.
\end{abstract}

Ключевые слова: видеоассистованая паратиреоидэктомии; лечение; первичный гиперпаратиреоз. 